very close punctuation, clypeus with lateral projectios angles; tongue apparently rather short, nearly as in Hemihalickis; mesothorax dull and granular from the excessively close punctures ; base of metathorax semilunar, with fine longitudinal plications or striae; tegulae piceous. Wings smoky, iridescent, nervures and stigma black or piceous; stigma rather small, basal nervure noiceably but not abruptly bent; second submarginal cell about as long as the first, receiving the first recurent nervure at less than one fourth from its base, and the second (at a right angle) about one-sixth from its tip. Legs black, with whitish hairs; hind legs with a rather abundant scopa, carrying considerable yellow pollen. Abdomen hardly punctured, except that the first segment near its base cxhibits large scattered punctures; hind margins of segments pallid; apical half of abdomen pruinose with pale hairs.

Hab.-Five taken by Prof. I. D. Tinsley at fowers of Gymolomia multiflora, in Solcdad Canon, Organ Mts., Ner Mesico, 7,000 feet alt, Sept. 25, 1897. I am not quite sure about the generic position of this little bee. The tongue suggests Hemihalictus, but the wings are entircly those of Halictoides and differ from Hemihalictus. I sent an example of H. Tinsleyi to Mr. W. J. Fox, who kindly compared it with Cresson's types of "Panurgus," and writes that it "is apparently different from any here. It is not fimbrialus, which has the abdomen wuch more hairy. It may be the $q$ of nigrifrons, but I am inclined to think not." (Litt., Nov. 5, 1897.)

\title{
ON THE DIPTEROUS GENUS EUSIPHONA
}

BY D. W. COQUILLETT, WASHINGTON, D. C.

At the time of establishing this genus, in my recent revision of the Tachinidae, I had only two specimens before me; in both of these the wings are bent backward in such a manner as to prevent a critical examination of the lower calypteres, but as the specimens otherwise agree quite closely with the Tachinid genus Gymnophania, I concluded to place the present genus next to it. The recent examination, however, of a perfect specimen from Mr. Charles Robertson, of Carlinville, Illinois, reveals the fact that the lower calypteres are extremely small, being, in fact, rudimentary, and this genus must therefore be transferred from the Tachinidae to the super family Acalyptrata. In all the essentist characters it agrees with the family Agromyzidae, and its proper place is evidently in the vicinity of the genus Desmometopa, from which it will be readily recognized by the strongly convex front and the excessively long, bristle-like proboscis. 